\title{
Seasonal variation in helminth parasites of snakeheads Channa punctatus and Channa striatus (Perciformes: Channidae) in Uttar Pradesh, India
}

\author{
N. KUMARI GAUTAM ${ }^{1 *}$, P. KUMAR MISRA², A. MURARI SAXENA ${ }^{1}$
}

1'Department of Zoology, University of Lucknow, Lucknow-226007, U. P. India, *E-mail: neelamkumari.gautam54@gmail.com; ${ }^{2}$ Department of Applied Animal Sciences, Babasaheb Bhimrao Ambedkar University, Lucknow-226025, U. P. India

\section{Article info}

Received October 5, 2017 Accepted May 15, 2018

\begin{abstract}
Summary
Snakehead fishes are widely consumed throughout South East Asia, China and India because of their good taste of meat and high nutrient values such as presence of prostaglandins, thromboxane and Omega-6 fatty acid. Parasitic infection constitutes significant economic loss in fish production. The aim of this work was to study the seasonal variation of helminths in snakeheads. In the presented study, a three-year survey has been performed. A total of 1013 individuals of Channa punctatus and 247 individuals of Channa striatus were examined. A total of 3783 helminths were collected, with an average of 3.02 helminths/fish. $43.50 \%$ individuals of $C$. punctatus and $59.10 \%$ of C. striatus were found to be infected with acanthocephalans, trematodes, nematodes and cestodes per year. The prevalence and mean abundance of Pallisentis sp. was at its peak in summer. However the prevalence of trematodes, nematodes and cestodes was at peak during autumn. Mean abundance of nematodes was at peak in summer. Interestingly, the males were found more infected as compared to the females and the infection rate in males peaked in summer. In comparison to other weight groups, medium size hosts $(21-40 \mathrm{~g})$ were found more consistently infected. Thus the results indicate that there are seasonal variations in parasitic helminths infecting $C$. punctatus and C. striatus which also depend upon sex and weight. These variations may be attributed to various environmental and biological factors including parasite life cycle and immune level of host.
\end{abstract}

Keywords: nematode; fish; helminths; parasites; prevalence; snakeheads

\section{Introduction}

A large proportion of proteins obtained from animal sources come from fishes. Out of total worldwide protein obtained by animal sources, $25 \%$ alone is contributed by fish and shellfish thus; fish is one of the most valuable sources of protein in food. About $80 \%$ infection of warm water fishes is caused by parasites (Eissa, 2002). Helminths play a key role in internal parasitic infections of fishes which leads to low body weight gain and high mortality rate. Parasitic infection either alone or in conjunction with stress may reduce host weight and reproduction which leads to economic loss (Rohde, 1993). Parasites also upset the normal reproduction of the hosts (Faust, 1940).

The infection of parasites interferes with nutrition, metabolism and secretory function of the alimentary canal, damages nervous system (Markov, 1961) which may also lead to gastrointestinal abrasions and facilitate the invasion by opportunistic microorganisms. Unfavorable environmental conditions contribute to stress which also weakens the immunity and opens the pathway to pathogens (Eissa, 2002). The study of diversity and distribution of helminths

\footnotetext{
* - corresponding author
} 
started in the middle of the $19^{\text {th }}$ century in India and numerous works has been done by Bhalerao, 1937; Gupta, 1984; Soota, 1981; Sood, 1989; Tondon et al., 2005; Bhure, 2008, Pandey \& Agrawal, 2008; Deshmukh, 2015 in different parts of India.

The distribution of helminths is not only affected by seasons but also by host age, size, diet, abundance of fishes and an independent number of parasites within the fish. Change in climatic conditions is predicted to affect the prevalence of parasites in freshwater and marine ecosystems. A study of Chubb (1977 \& 1979) showed the seasonal occurrence of helminths of freshwater fishes from different climatic zones.
Price and Clancy (1983) had also reported that larger bodied fish species harbor more parasitic diversity than small-bodied fish, but according to Sasal et al. (1997) there is no association between fish body size and parasite species richness. Available data on factors which potentially control the number of parasite species in freshwater and marine fishes (Sasal et al., 1997; Luque \& Poulin, 2004) are very little in consistency. Moreover, available studies on the helminth parasitic fauna of snakeheads in relation to seasonal population dynamics, size and sex of the host are very little. The aim of this study was to investigate the seasonal variation of parasitic helminths of freshwater fishes from Uttar Pradesh, India with relation to host sizes and sex.
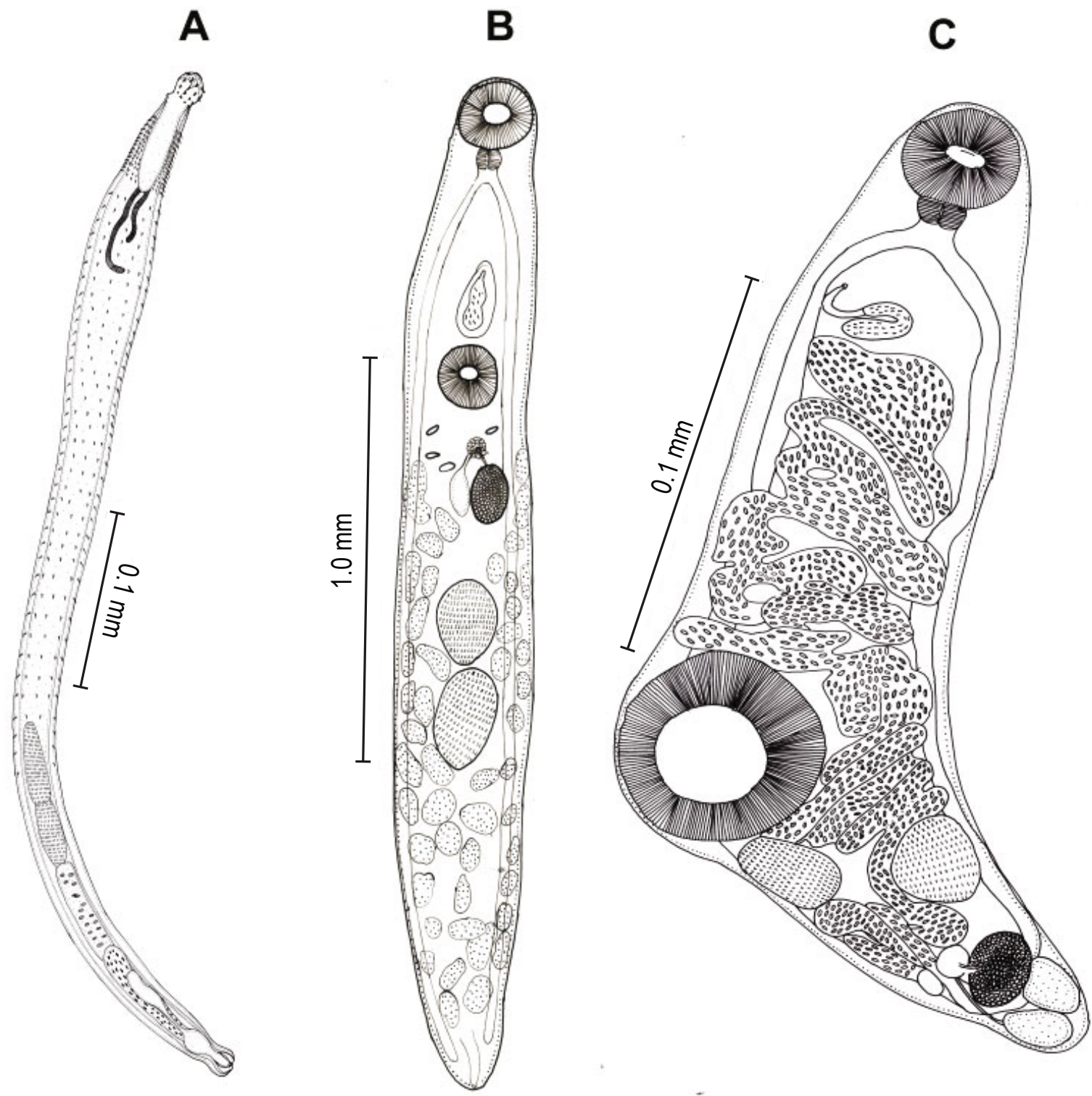

Fig. 1. Line drawings of Acanthocephalan and Trematodes: A) Pallisentis sp. B) Allocradium sp. C) Genarchopis sp. 


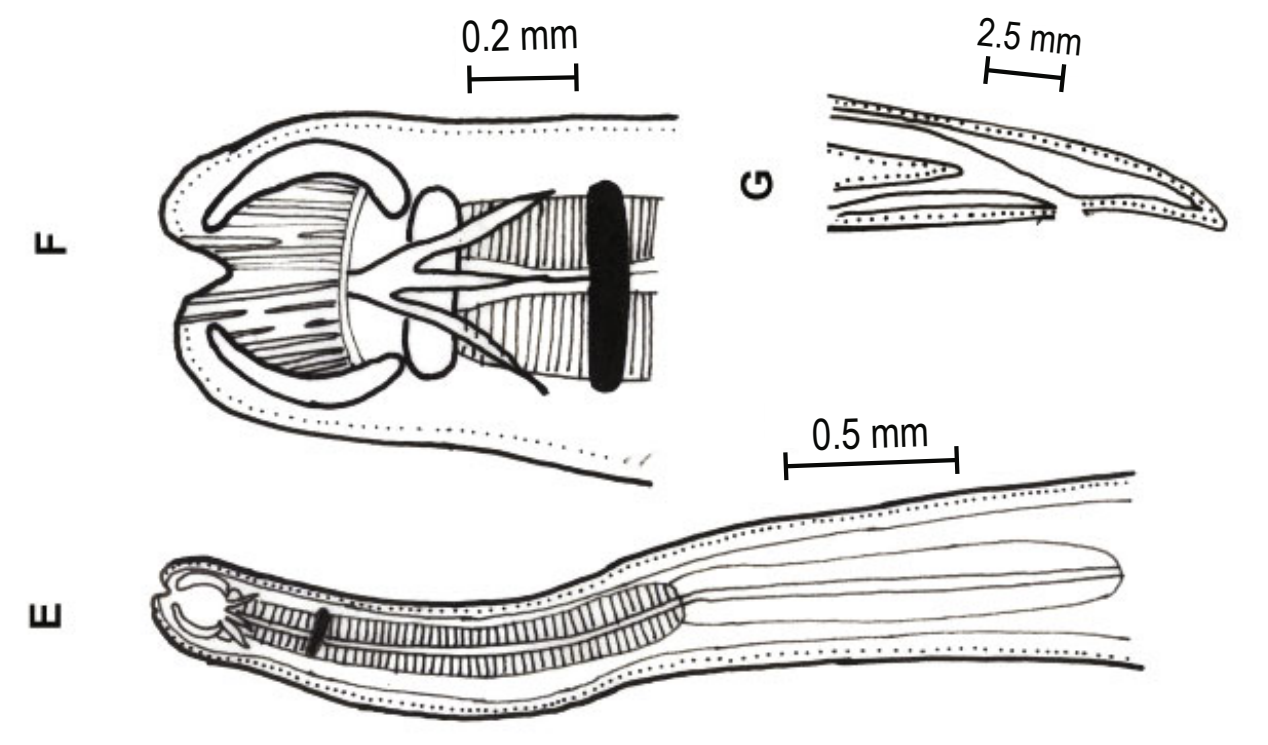

(4)

के के

蛋

离
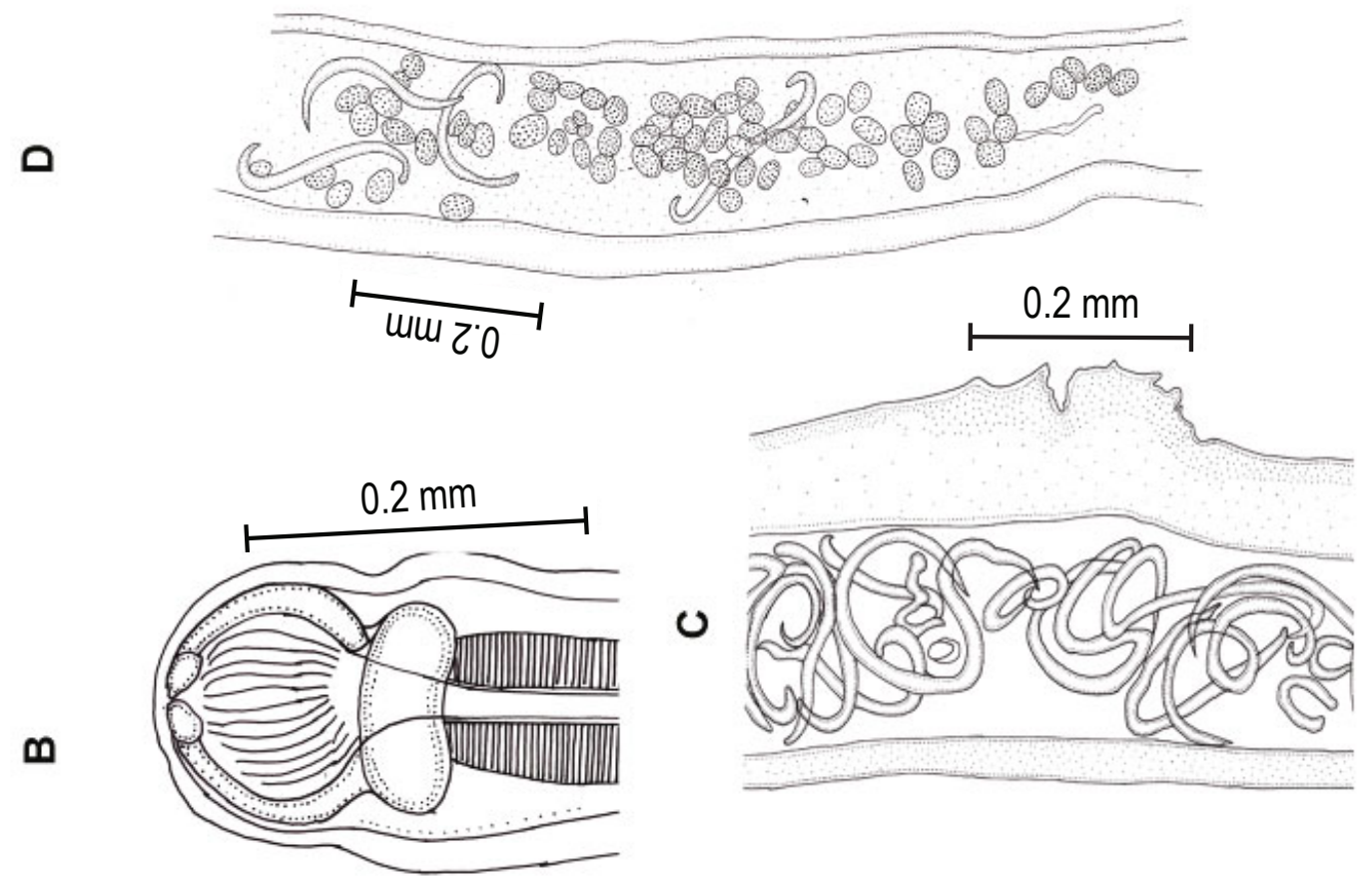

0
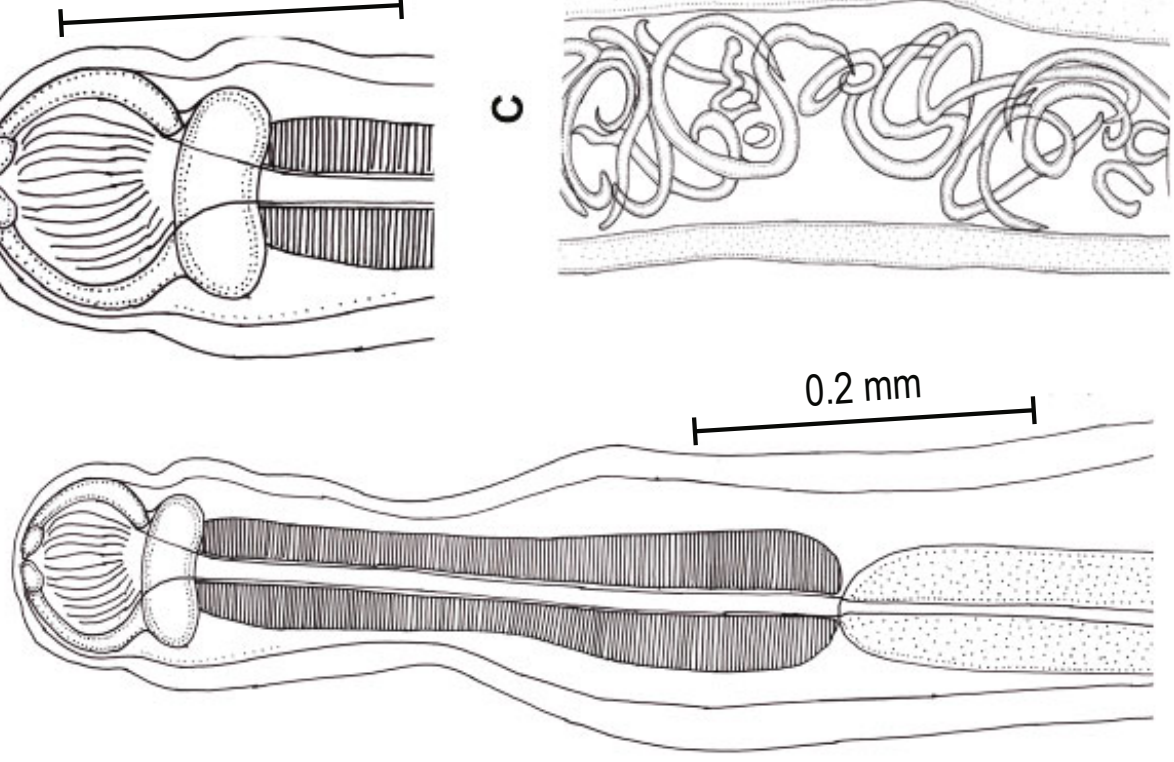

क्ष 


\section{Materials and Methods}

A three-year survey (September 2013 to August 2016) was performed. Fish samples were collected four times in a year during winter (December - February), autumn (September - November), summer (March - May) and rainy season (June - August). Fishes were collected from water bodies near Lucknow $\left(26^{\circ} 84^{\prime} 67^{\prime \prime} \mathrm{N}\right.$; $\left.80^{\circ} 94^{\prime} 62^{\prime \prime} \mathrm{E}\right)$. Fishes were weighed, measured and identified according to Vazzoler (1996).

Bodies were opened along the midventral line from the anal region to the mouth. The surface of the visceral organs, intestine and the body cavity were examined carefully. The alimentary ca- nal was separated and kept in Petri dishes containing normal saline $(0.9 \%)$. The stomach and intestine were opened to dislodge parasites. A few drops of the methanol were added to the normal saline, containing the parasites adhered to the intestinal wall for immobilization and loosening of the grip on the intestinal wall.

Live specimens of parasites collected from the stomach and intestine of host and were kept in normal saline. Parasites were flattened with the help of a glass cover slip and fixed in AFA \{Alcohol (50\%): formalin: acetic acid (100: 6: 2.5)\}. Specimens were stained with acetoalum carmine, dehydrated in ascending grades of ethanol (30\%, $50 \% 70 \%, 90 \%$ and absolute ethanol), cleared in xylene and mounted in DPX. Figures were drawn with

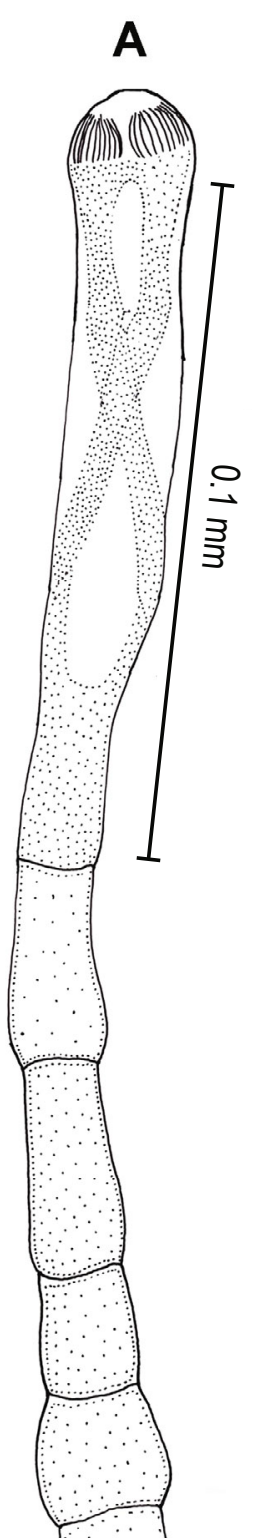

B

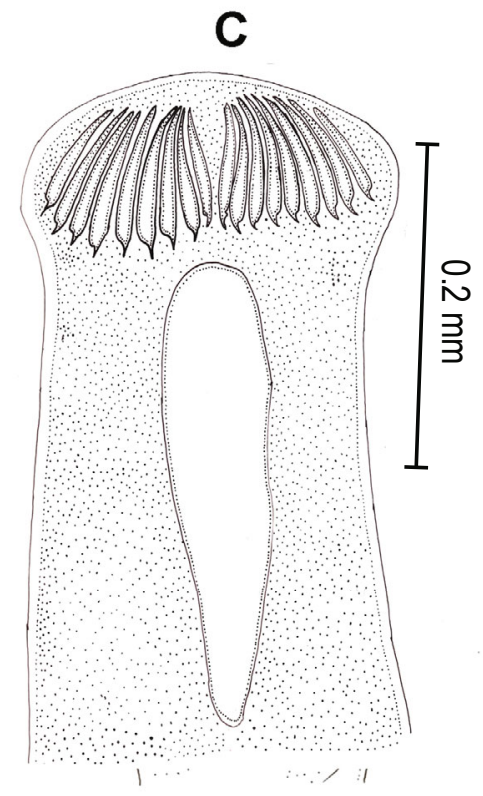

$\mathbf{E}$

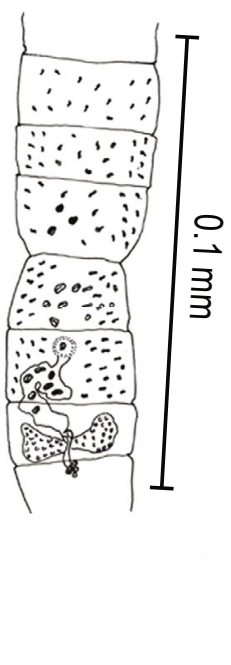

D

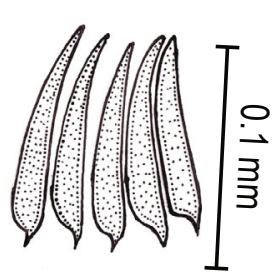

$\mathbf{F}$

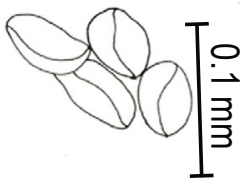

Fig. 3. Line drawings of Senga sp. A) Scolex and neck. B) Apical disc of scolex with hooks. C) Enlarge view of scolex. D) Enlarge view of scolex hooks. E) Mature proglottid. F) Eggs. 
Camera Lucida, attached to Phase Contrast Microscope (Olympus CX-41). Parasites were identified up to genus level by using the keys of Yamaguti, 1958; Rego et al., 1999; Amin et al., 2000; Bhattacharya, 2007 and Gibbons, 2010. The slides of collected specimens were deposited in the "Helminthology lab, Department of Zoology, University of Lucknow, U.P., India. Collection numbers: LU/Z/2017/13, LU/Z/2017/14, LU/Z/2017/15, LU/Z/2017/16, LU/Z/2017/17 and LU/Z/2017/18 were assigned for Pallisentis sp., Allocredium sp., Genarchopsis sp., Neocamallanus sp., ProcamaIlanus sp. and Senga sp. respectively.

Only the species that had prevalence equal or greater than $10 \%$ in at least one of the collections were further included in the analysis. Prevalence, intensity range, mean intensity and mean abundance were calculated following Rohde et al. (1995). Possible differences between the prevalence in different seasons in relation to total samples were evaluated with Kruskal-Wallis $\mathrm{H}$ test .The Wilcoxon Sign Rank test was used for the analysis of infection in male and female. We set the null hypothesis, $\mathrm{H}_{0}$ : infection in male and female were equal. i.e. $p_{1=} p_{2}$. We also set alternate hypothesis, $H_{1}$ : Infection in male and female were not the same. i.e. $p_{1 \neq} p_{2}$. From the given data we got interested in testing whether the infection in male and female C. punctatus and C. striatus are same or different.

The ecological terminology used was recommended by Bush et al. (1997). The level of statistical significance was $p<0.05$.

\section{Ethical Approval and/or Informed Consent}

Animal care and handling were carried out in accordance with national guidelines.

\section{Results}

A total of 1013 individuals of C. punctatus and 247 individuals of C. striatus were examined. Overall 3783 helminths were found with an average of 3.02 helminths/fish collected. On an average $43.50 \%$ C. punctatus and $59.10 \%$ C. striatus were found to be infected with Acanthocephalans (Pallisentis sp., Fig.1A), trematodes (Allocredium sp. Fig.1B and Genarchopsis sp. Fig.1C), nematode (Neocamallanus sp. Fig.2A-2D and Procamallanus sp. Fig.2E$2 \mathrm{G}$ ) and cestodes (Senga sp. Fig.3A-3F ) per year.

The prevalence, intensity range, mean intensity and mean abundance of various helminths in $C$. punctatus and $C$. striatus were observed (Table 1). The digestive tract was found to be harbouring one acanthocephalan, two trematodes, two nematodes and one cestode genus. Acanthocephalan Pallisentis spp. was the most prevalent and abundant parasite $(46.50 \%$ infected specimen in C. punctatus and $59.11 \%$ in C. striatus). We could find only one cestode Senga sp. in both C. punctatus and C. striatus

The highest mean intensity and abundances were found in Pallis-

Table 1. Prevalence, intensity range, mean intensity and mean abundance of helminths of snake headed fishes in Uttar Pradesh, India.

\begin{tabular}{|c|c|c|c|c|c|c|}
\hline & Parasites & Prevalence (\%) & Intensity range & Mean Intensity \pm SD & Mean Abundance \pm SD & Site of infection \\
\hline \multirow{8}{*}{ 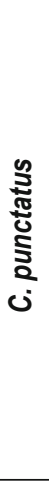 } & Acanthocephala & & & & & \\
\hline & Trematode & & & & & \\
\hline & Allocredium sp. & 21.74 & $2.78-0.00$ & $0.97 \pm 0.79$ & $0.23 \pm 0.25$ & Intestine \\
\hline & Genarchopsis sp. & 19.66 & $3.68-0.17$ & $1.31 \pm 0.98$ & $0.30 \pm 0.28$ & Stomach \\
\hline & Nematode & & & & & \\
\hline & Procamallanus sp. & 14.53 & $3.83-0.00$ & $1.38 \pm 0.95$ & $0.25 \pm 0.25$ & Intestine \\
\hline & Cestode & & & & & \\
\hline & Senga sp. & 13.04 & $2.25-0.00$ & $1.21 \pm 0.68$ & $0.20 \pm 0.21$ & Stomach and Intestine \\
\hline \multirow{8}{*}{ 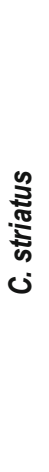 } & Pallisentis sp. & 59.11 & $20.21-0.13$ & $5.11 \pm 6.92$ & $3.42 \pm 5.98$ & Intestine \\
\hline & Trematode & & & & & \\
\hline & Allocredium sp. & 26.32 & $7.78-0.00$ & $2.00 \pm 2.21$ & $0.56 \pm 0.78$ & Intestine \\
\hline & Genarchopsis sp. & 18.62 & $3.22-0.00$ & $1.15 \pm 1.01$ & $0.28 \pm 0.43$ & Stomach \\
\hline & Nematode & & & & & \\
\hline & Neocamallanus sp. & 17.81 & $7.60-0.00$ & $1.70 \pm 2.11$ & $0.36 \pm 0.51$ & Intestine \\
\hline & Cestode & & & & & \\
\hline & Senga sp. & 14.57 & $7.50-0.33$ & $2.15 \pm 2.37$ & $0.27 \pm 0.31$ & Stomach and Intestine \\
\hline
\end{tabular}


Table 2. Seasonal differences in the prevalence (\%) (Mean \pm SD) of helminths in snakehead fishes U. P. India.

\begin{tabular}{|c|c|c|c|c|c|c|}
\hline \multirow{2}{*}{$\begin{array}{l}\text { 해 } \\
\text { 오 }\end{array}$} & \multirow{2}{*}{$\begin{array}{l}\text { Parasites } \\
\text { Seasons }\end{array}$} & \multirow{2}{*}{$\begin{array}{l}\text { Acanthocephala } \\
\text { Pallisentis sp. }\end{array}$} & \multicolumn{2}{|c|}{ Trematode } & \multirow{2}{*}{$\begin{array}{c}\text { Nematode } \\
\text { Procamallanus sp. }\end{array}$} & \multirow{2}{*}{$\begin{array}{l}\text { Cestode } \\
\text { Senga sp. }\end{array}$} \\
\hline & & & Allocredium sp. & Genarchopsis sp. & & \\
\hline \multirow{7}{*}{ 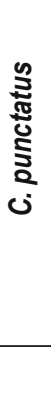 } & Autumn & $68.85 \pm 3.83$ & $18.19 \pm 4.12$ & $22.35 \pm 5.96$ & $22.09 \pm 18.62$ & $29.93 \pm 21.97$ \\
\hline & Winter & $34.79 \pm 9.68$ & $25.15 \pm 13.96$ & $15.67 \pm 4.15$ & $13.94 \pm 7.98$ & $11.66 \pm 6.58$ \\
\hline & Summer & $65.21 \pm 5.90$ & $27.71 \pm 5.93$ & $22.19 \pm 6.17$ & $18.38 \pm 2.94$ & $12.03 \pm 1.10$ \\
\hline & Rainy & $36.47 \pm 11.64$ & $26.26 \pm 10.00$ & $24.87 \pm 9.68$ & $20.30 \pm 7.41$ & $13.28 \pm 3.64$ \\
\hline & Chi-square & 8.641 & 2.487 & 1.974 & 1.564 & 1.051 \\
\hline & $\mathrm{p}$-value & 0.034 & 0.478 & 0.578 & 0.668 & 0.789 \\
\hline & & Pallisentis sp. & Allocredium sp. & Genarchopsis sp. & Neocamallanus sp. & Senga sp. \\
\hline \multirow{6}{*}{ 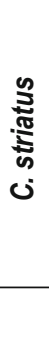 } & Autumn & $66.72 \pm 5.23$ & $37.02 \pm 15.00$ & $34.48 \pm 12.36$ & $25.48 \pm 9.97$ & $18.87 \pm 6.62$ \\
\hline & Winter & $22.22 \pm 11.11$ & $11.11 \pm 11.11$ & $25.93 \pm 16.97$ & $7.41 \pm 6.42$ & $18.52 \pm 6.42$ \\
\hline & Summer & $79.97 \pm 9.50$ & $28.79 \pm 4.67$ & $2.66 \pm 2.43$ & $19.46 \pm 6.49$ & $10.14 \pm 2.51$ \\
\hline & Rainy & $40.15 \pm 6.44$ & $16.53 \pm 6.93$ & $14.69 \pm 9.28$ & $11.60 \pm 2.34$ & $13.35 \pm 5.78$ \\
\hline & Chi-square & 9.974 & 7.667 & 7.821 & 7.539 & 5.539 \\
\hline & $\mathrm{p}$-value & 0.019 & 0.053 & 0.050 & 0.057 & 0.136 \\
\hline
\end{tabular}

entis sp. while the trematode Allocredium sp. and cestode Senga sp. were least abundant in $C$. punctatus and $C$. striatus respectively. There were statistically significant differences of prevalence between different seasons of Pallisentis spp. in C. punctatus $(p=$ $0.034)$ and $C$. striatus $(p=0.019)$. But there were no significant differences in other helminths in either $C$. punctatus or $C$. striatus (Table 2). The prevalence of Pallisentis spp. was maximum in autumn and summer in C. punctatus $(68.85 \pm 3.83$ and 65.21 \pm 5.90 respectively) while in $C$. striatus, prevalence of $P$ allisentis spp. was maximum during summer $(79.97 \pm 9.50)$.

Mean abundance of most of the helminths species was higher during summer and never reached maximum observed during winter season (Table 3). Acanthocephalans and nematodes in both the host attained peak mean abundance during summer while trematode Genarchopis sp. in C. punctatus and Allocradium sp. in C. striatus showed maximum during rainy season. Only cestode Senga sp. in C. punctatus and trematode Genarchopis sp. in C. striatus showed maximum mean abundance during autumn.

Infection rates of parasitic helminths were observed for different sexes in changing seasonal conditions to study the effect of sex on infection. There was a statistically significant difference between the infection rates of male and female C. punctatus and C. striatus (Table 4). During all the seasons except autumn in C. punctatus and throughout all the seasons in $C$. striatus there were significantly higher infected males as compared to females.

Comparing different weight groups in hosts, we found that there was a tendency in medium weight group $(21-40 \mathrm{~g})$ to become more infected. In C. punctatus weight group $60-200$ was infected most while as regards to the $C$. striatus in $21-40$ weight group it was autumn season (Table 5). In winter season the infection rates were higher in the weight group of $21-40$ for both C. punctatus and $C$. striatus. The infection rates in summer season were highest in weight group $41-60$ in C. punctatus and in weight group $00-20$ in C. striatus. In the rainy season, the highest prevalence of the infection was in the weight group $21-40$ and $41-60$ in C. punctatus and $C$. striatus respectively.

\section{Discussion}

The present study on two snakehead fishes was aimed to survey the occurrence and distribution of endoparasitic helminths and to explore the seasonal prevalence of these parasites. Six genera of helminths were found from trematode, cestode, nematode and acanthocephalans. Most of the parasites were found in the intestine region and the acanthocephalan Pallisantis spp. were most prevalent ones.

Seasonal variations of parasites in the host are already well studied. Distinct seasonal variation was reported by Boping and Wang (2007) and they found that the prevalence of Pallisentis caelatus (Neosentis) was at the highest in spring and decreased with fall in temperature. Earlier, Kanth and Srivastava (1987) had also reported that infestation rate of Pallisentis ophiocephali gradually increases and achieves two peaks in May and August. In our study, the infection rate differed seasonally and the maximum parasites were generally found during autumn and summer seasons. Among the nematode and cestode, peak prevalence was in autumn in both hosts, following the end of the peak breeding period of the host fishes. The Prevalence of trematode was not similarly regular 
Table 3. Seasonal differences in mean abundance of helminths of snakeheaded fishes in U. P. India.

\begin{tabular}{|c|c|c|c|c|c|c|}
\hline Host & Parasites & Total & Autumn & Winter & Summer & Rainy \\
\hline \multirow{9}{*}{ 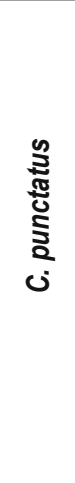 } & Acanthocephala & & & & & \\
\hline & Pallisentis sp. & 0.96 & 0.72 & 0.66 & 0.89 & 0.85 \\
\hline & Trematode & & & & & \\
\hline & Allocredium sp. & 0.54 & 0.40 & 0.33 & 0.72 & 0.58 \\
\hline & Genarchopsis sp. & 0.50 & 0.46 & 0.40 & 0.55 & 0.60 \\
\hline & Nematode & & & & & \\
\hline & Procamallanus sp. & 0.54 & 0.53 & 0.42 & 0.58 & 0.54 \\
\hline & Cestode & & & & & \\
\hline & Senga sp. & 0.46 & 0.62 & 0.44 & 0.45 & 0.33 \\
\hline \multirow{9}{*}{ 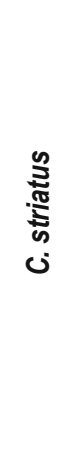 } & Acanthocephala & & & & & \\
\hline & Pallisentis sp. & 0.82 & 0.75 & 0.66 & 0.85 & 0.85 \\
\hline & Trematode & & & & & \\
\hline & Allocredium sp. & 0.46 & 0.31 & 0.40 & 0.66 & 0.80 \\
\hline & Genarchopsis sp. & 0.65 & 0.88 & 0.33 & 0.60 & 0.66 \\
\hline & Nematode & & & & & \\
\hline & Neocamallanus sp. & 0.30 & 0.23 & 0.22 & 0.50 & 0.33 \\
\hline & Cestode & & & & & \\
\hline & Senga sp. & 0.33 & 0.35 & 0.40 & 0.42 & 0.18 \\
\hline
\end{tabular}

and differed in both hosts. For $\mathrm{C}$. striatus the peak was in autumn but $C$. punctatus attained its peak in both summer and rainy seasons. Many authors have also reported that high prevalence of cestode (Bhure et al., 2014) in summer whereas low in the monsoon season. Similarly Vincent and Font (2003) reported that the prevalence, mean abundance and mean intensity of nematodes were higher in summer than in winter. According to Genc et al., (2005) the parasitic infection showed seasonal variations with the highest prevalence in the summer season.

Two main categories of factors may be held responsible for the seasonal variations in host infectivity, those linked to the host and other linked to the parasites. Ibiwoye et al., (2004) observed that susceptibility to infections in fishes are generally due to weakened body after hibernation. According to Bhuiyan et al., (2007) decrease in water volume during dry seasons results in imbalanced nutritional conditions also make fishes vulnerable to the infections. The authors also concluded that decreased water temperature also made the hosts susceptible to infections by weakening immune systems. So many other parasite associated factors are also held responsible for the development of parasites such as high temperature and

Table 4. Seasonal differences of helminths of $C$. punctatus and $C$. striatus during different seasons.

\begin{tabular}{|c|c|c|c|c|c|}
\hline Host & Seasons & Male & Female & Z & $p^{*}$ \\
\hline \multirow{4}{*}{ 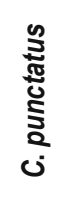 } & Autumn & $6.22 \pm 6.01$ & $2.33 \pm 1.73$ & 1.90 & 0.057 \\
\hline & Winter & $6.11 \pm 6.60$ & $0.44 \pm 0.72$ & 2.03 & 0.042 \\
\hline & Summer & $20.33 \pm 18.01$ & $4.55 \pm 2.35$ & 2.36 & 0.018 \\
\hline & Rainy & $5.22 \pm 7.67$ & $1.88 \pm 3.14$ & 2.13 & 0.033 \\
\hline \multirow{4}{*}{ 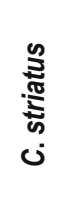 } & Autumn & $4.33 \pm 2.23$ & $1.66 \pm 1.22$ & 2.55 & 0.011 \\
\hline & Winter & $2.11 \pm 1.26$ & $1.11 \pm 1.05$ & 2.04 & 0.041 \\
\hline & Summer & $6.66 \pm 7.36$ & $0.88 \pm 1.36$ & 2.37 & 0.018 \\
\hline & Rainy & $2.66 \pm 2.00$ & $0.88 \pm 1.36$ & 2.45 & 0.014 \\
\hline
\end{tabular}

$\mathrm{Z}$ value of Kruskal-Wallis $\mathrm{H}$ test, ${ }^{*}$ significance level $p \leq 0.05$ 
Table 5. Helminths infecting Channa punctatus and Channa striatus of different weight groups as $00-20 \mathrm{~g}, 21-40 \mathrm{~g}, 41-60 \mathrm{~g}$ and $61-200 / 300 \mathrm{~g}$.

\begin{tabular}{llcccc}
\hline & & \multicolumn{4}{c}{ Weight $(\mathbf{g})$} \\
\cline { 3 - 6 } Host & Seasons & $\mathbf{0 0 - 2 0}\left(\mathbf{p}_{1}\right)$ & $\mathbf{2 1 - 4 0}\left(\mathbf{p}_{2}\right)$ & $\mathbf{4 1 - 6 0}\left(\mathbf{p}_{3}\right)$ & $\mathbf{6 0 - 2 0 0 / 3 0 0}\left(\mathbf{p}_{4}\right)^{*}$ \\
\hline C. punctatus & Autumn & 26.3 & 48.75 & 7.69 & 70.0 \\
& Winter & 18.30 & 51.28 & 31.25 & 13.33 \\
& Summer & 50.0 & 52.90 & 59.23 & 51.28 \\
& Rainy & 36.20 & 78.76 & 39.47 & 0.00 \\
\hline C. striatus & Autumn & 64.15 & 76.08 & 50.0 & 0 \\
& Winter & 46.66 & 75.55 & 71.42 & 50.0 \\
& Summer & 90.0 & 73.33 & 34.48 & 11.53 \\
& Rainy & 0 & 26.66 & 32.14 & 11.76 \\
\hline
\end{tabular}

${ }^{*}$ Channa punctatus maximum weight was $200 \mathrm{~g}$ and Channa striatus $300 \mathrm{~g}$.

low rainfall (Jadhav \& Bhure, 2006). Kennedy (1970 \& 1977) had explained that feeding habits of the host, availability of infective host and parasite maturation are also responsible for influencing the parasitic infections. Recently, Sheema et al., (2015) and Ritika et al., (2012) have suggested that abundance of helminths increase with the rising temperature in summer and slow down during winter. The development of intermediate hosts of helminths during summer season also leads to better availability of infective stages resulting in higher helminths prevalence in summer (Khurshid \& Ahmad, 2012).

During our study we also found significant differences in infestation rates on the basis of sex and weight groups. In overall four different seasons, the infestation rate in male $\mathrm{C}$. punctatus was higher in the summer. The association between reproduction and increase in prevalence and abundance of parasites has been attributed the fact to the physiological stress of the host during the breeding period, as a higher investment in reproduction may decrease the energy allocated to the immune system and thereby facilitate parasitic infestation (White et al., 1996; Lizama et al., 2006). There are contrasting reports in this regard as some authors have observed more infection in male hosts as compared to females (Zelmer \& Arai, 1998) and this view is supported by our study. Other observers have reported a greater susceptibility of females (Ibiwoye et al., 2004; Singhal \& Gupta, 2009). These differences may be because of various factors including host species, infective species and geographical conditions.

Variations in infection rates in different weight group were less profound in summer where in the rest seasons, there were more variations. Overall, the mid-weighed snakeheads were more prone to infection as compared to lower and higher weight groups. Our results are in accordance with some earlier observations. Nahar (1988) have also reported similar finding that the hosts with intermediate size were more infected by the parasites than the smaller and larger individuals. Similar reports by Polyanski (1961) had supported the view that intermediate length and weight group host had a higher prevalence and intensity than those of smaller and larger length and weight group. Major factors such as food, lifespan, variety of habitats, population density and size attained by host were suggested to affect the parasites prevalence and intensity in fish.

Our study explores the diversity and seasonal variations of helminthic parasites in snakeheads. Our study explores the diversity and seasonal variations of helminthic parasites in snakeheads. These types of studies will lead to the better understandings of host-parasite interactions what will be beneficial for the improvement of infectious diseases management and also contribute to the increase in fish production.

\section{Acknowledgment}

We thank the University Grants Commission, New Delhi for the financial assistance through the Rajeev Gandhi National Fellowship (F1-17.1/2013-14/RGNF-2013-14-SC-UTT-43684 /(SAIII/ Website).

\section{Conflict of Interest}

Authors state no conflict of interest.

\section{References}

Amin, O.M., Heckemann, R.A., Van, Ha, N., Luc, P.V., Doanh, P.N. (2000); Revision of the genus Pallisentis (Acanthocephala: Quadrigyridae) with the erection of three New sub-genera, the description of Pallisentis (Bervitritospinus) vietnamensis subgen. et $\mathrm{sp}$. $\mathrm{n}$., a key to the species of Pallisentis, and the description of a new Quadrigyrid genus, Pararaosentis gen. n. Comp. Parasitol., 67(1): $40-50$

BhaleraO, G.D. (1937): Studies on the Helminths of Indian Trematoda, IV. J. Helminthol., 15 (2): 97 - 124. DOI: 10.1017/ S0022149X00030753 
Bush, A.O., Lafferty, K.D., Lotz, J.M., Shostak, A. W. (1997): Parasitology meets ecology on its own terms: Margolis et al. revisited. J. Parasitol., 83(4): 575 - 583. DOI: 10.2307/3284227

BhatTaChaRYA, S.B. (2007): Handbook on Indian Acanthocephala. Kolkata, India, Zoological Survey, 225pp.

Boping, Z., Wang, W. (2007): Seasonal population dynamics of Pallisentis (Neosentis) celatus (Acanthocephala: Quadrigyridae) in the intestine of the rice-field eel Monopterus albus in China. J. Helminthol., 81:415 - 420. DOI: 10.1017/S0022149X07868799

BHURE, D.B. (2008): Faunal diversity of Helminth parasites of freshwater fishes of Maharashtra State, India. PhD, thesis, India, Aurangabad: Dr. B. A. M. University

BhuiYan, A.S., Akter, S., Musa, G.M. (2007): Occurrence of parasites in Labeo rohita (Hamilton) from Rajshahi University. J. Zool. Rajshahi Univ., 26: 31 - 34

Bhure, D.B., Nanware, S.S. (2014): Studies on Prevalence of Cestode Parasites of Freshwater Fish, Channa punctatus. J. Entomol. Zool. Stud., 2(4): $283-285$

CHuBB, J.C. (1977): Seasonal occurrence of helminth in freshwater fishes. Part I Monogenea. In: Dawes, B. (Ed) Advances in Parasitology. London, UK: Academic Press and, pp.133 - 199. DOI: 10.1016/S0065-308X(08)60528-X

CHuBB, J.C. (1979): Seasonal occurrence of helminths in freshwater fishes. Part II Trematoda. In: Lumsden, W.H.R.R., Muller, R., Baker, J.R. (Eds) Advances in Parasitology. London, Academic Press and, pp. 142 - 313. DOI: 10.1016/S0065-308X(08)60398-X DeshmukH V. S. (2015): Biosystematics studies on some Helminth Parasites of freshwater fishes. PhD thesis, India, Nanded: S.R.T.M. University

EISSA, I.A.M. (2002): Parasitic fish infections in Egypt. In: DAR EL-NAHDDA $1^{\text {st }}$ (Ed) El-Arabia Publishing pp. 52 - 53

FAust, E.C. (1940): Human helminthology: A manual for physicians, sanitarians and medical zoologists. Philadelphia, USA, Lea \& Febriger, $744 \mathrm{pp}$.

GUPTA, P.D. (1984): Helminthology in India in $18^{\text {th }}-19^{\text {th }}$ centuries with some remarks on its recent progress. Ind. J. Hist. Sci., 19: $109-117$

Genc, E., Genc, A.M., Genc, E., Cengizler, I.C., Fatih, M.C. (2005): Seasonal Variation and Pathology Associated with Helminthes Infecting Two Serranids (Teleostei) of Iskenderun Bay (Northeast Mediterranean Sea), Turkey. Tur. J. Fish. Aqu. Sci., 5: 29 - 33

GibBons, L.M. (2010): Keys to the Nematode Parasites of Vertebrates. Supplementary Volume, Wallingford, UK, CAB International, $416 \mathrm{pp}$.

Ibiwoye, T.I.l., Balogun, A.M., Ogunsusi, R.A., Agbontale, J.J. (2004): Determination of the infection densities of mudfish Eustrongyloides in Clarias gariepinus and C. anguillaris from Bida flood plain of Nigeria. J. Appl. Sci. Environ. Manage, 8: 39 - 45 JadHAV, B.V., BHURE, D.B. (2006): Population dynamics of Helminth parasites in freshwater fishes from Marathwada region (M. S.) India. Flora and Fauna, 12(2): 143 - 148

Kennedy, C.R., Mine, D.M. (1970): Population biology of the Ces- tode Proteocephalus torulisus (Bat Sch) in dace Leucisus leucisus (L) of the river Avon. J. Fish. Biol., 1(3): 209 - 219. DOI: 10.1111/ j.1095-8649.1969.tb03854.x

KENNEDY, C.R. (1977): The regulation of fish parasite populations. In: Esch, G.W. (Ed) In regulation of parasite population. New York: Acedmic press, pp. $61-109$

Kanth, L.K., SRIVAstaVA, L.P. (1987): The occurrence of Metaclinostomum srivastavai (Pandey and Baugh, 1969) (Digenea), Genarchopsis goppo (Tubangui) Ozaki, 1925 (Digenea) and Pallisentis ophiocephali (Rai, 1967) (Acanthocephala) in the fresh water fish, Channa punctatus (Bloch). Ind. J. Parasitol., 11: 155 - 157

KhURSHID, I., Ahmad, F. (2012): Gastro-Intestinal Helminth Infection in fishes relative to season from Shallabugh Wetland. Int. J. Recent Sci. Res., 3(4): $270-272$

LUQUe, J. L., POULIN, R. (2004): Use of fish as intermediate hosts by helminth parasites: a comparative analysis. Acta Parasitol., 49: $353-361$

Lizama, M.A.P., Takemoto, R.M., Pavanelli, G.C. (2006): Influence of the seasonal and environmental patterns and host reproduction on the metazoan parasites of Prochilodus lineatus. Braz. Arch. Biol. Technol., 49(4): 611 - 622. DOI: 10.1590/S151689132006000500011

MARKov, G.S. (1961): Physiology of fish parasites. In: Dogiel, V.A., Petrushevesky, G.K. Polyansky, Yu. I. (Eds) Parasitology of Fishes. London, Edinburg, pp. 117 - 139

NAHAR, N. (1988): Prevalence and intensity of helminth parasites of Xenentodon cancila (Hamilton, 1822) in relation to some of its biological aspect. M. Sc. thesis, Dhaka, Eden Mohilla College.

Polyanski, Y.I. (1961): Ecology of parasites of marine fishes. In: Dogiel, V.A., Petrushevski, G.K., Polyanski, Y.I. (Eds) Parasitology of fishes. London, Oliver and Boyd, pp. 48 - 83.

Price, P.W., Clancy, K.M. (1983): Patterns in a number of helminth parasite species in freshwater fishes. J. Parasitol., 69: 449 - 454. DOI: $10.2307 / 3281352$

Pandey, K.C., Agrawal, N. (2008): An encyclopedia of Indian Monogenoidea. New Delhi, Vitasta Publishing Pvt Ltd, pp. 552.

ROHDE, K. (1993): Ecology of Marine Parasites, an Introduction to Marine Parasitology. $2^{\text {nd }}$ Edition, CAB International.

Rohde, K., Hayward, C., HeAP, M. (1995): Aspects of the ecology of metazoan ectoparasites of marine fishes. Int. J. Parasitol., 25(8): 945 - 970. DOI: 10.1016/0020-7519(95)00015-T

Rego A.A., Chubb J.C., Pavanelli G.C. (1999): Cestodes in South American freshwater teleost fishes: keys to genera and brief description of species. Rev. Brasil. Zool., 16: 299 - 367

Ritika, R.S., GiRdhar, G.A., Agrawal, N. (2012): Seasonal variation in monogenoid abundance on Puntius sp. Res. J. Biol., 2: $186-190$ Sasal, P., Morand, S., Egan, G.U. (1997): Determinants of parasite species richness in Mediterranean marine fish. Mar. Ecol. Prog. Ser., 149: 61-71. DOI: 10.3354/meps149061

SootA, T.D. (1981): On some nematodes from the unnamed collection of the zoological survey of India, along with the description of a new species. Rec. Zool. Surv. Ind., 79: $55-71$ 
Sood, M.L. (1989): Fish nematodes from South Asia. India, Kalyani Publisher, $389 \mathrm{pp}$.

Tondon, V., Kar, P. K., Das B., Sharma, B., DorJee, J. (2005): Preliminary survey of gastrointestinal helminth infection in herbivorous livestock of mountainous regions of Bhutan and Arunachal Pradesh. Zoo. Print. J., 20: 1867 - 1868. DOI: 10.11609/JoTT. ZPJ.1227.1867-8

SINGHAL, P., GUPTA, N. (2009): Genarchopsis infestation in relation to host length and sex in freshwater murrel, Channa. Biospectra. 4: $257-260$

Sheema, S.H., John, M.V., George, P.V. (2015): Seasonal variations in the infection of acanthocephalan parasite Echinorhynchus veli (George \& Nadakal) on oriental sole Brachirus orientalis (Bloch \& Schneider). J. Aquatic Biol. Fish., 3:115 - 120

VAzzoler, A.E.A.M. (1996): Biologia da reprodução de peixes teleósteos: teoria e prática [Reproductive biology of teleost fish: the- ory and practice]. Eduem sbi, São Paulo, 169 pp. (In Portuguese) VINCENT, A.G., Font, W.F. (2003): Seasonal and yearly population dynamics of two exotic helminths, Camallanus cotti (Nematoda) and Bothriocephalus acheilognathi (Cestoda), parasitizing exotic fishes in Waianu stream, O'Ahu, Hawaii. J. Parasitol., 89: 756 760. DOI: 10.1645/GE-90R

White, K.A.J., Grenfel, B.T., Hendry, R.J., Lejeune, O., Murray, J.D. (1996): Effect of seasonal host reproduction on host-macroparasite dynamics. Math. Biosci., 137(1): 79 - 99. DOI: 10.1016/ S0025-5564(96)00061-2

Yamaguti, S. (1958): Systema Helminthum. Vol 1. The Digenetic Trematodes of Vertebrates. Interscience Publishers Inc. New York. ZeLmer, D.A., ArAl, H.P. (1998): The contributions of host age and size to the aggregated distribution of parasites in yellow perch, Perca flavescens, from Garner Lake, Alberta Canada. J. Parasitol., 84: 24 - 29. DOI: 10.2307/3284522 